\title{
Headstarting Turtles-Is it a Valid Strategy for Wildlife Rehabilitators?
}

\author{
HARRIET ForRESTER \\ Turtle Rescue of NeW Jersey \\ HARDWICK, NEW JERSEY
}

\section{INTRODUCTION}

Headstarting is the hatching and rearing of turtles in captivity until they reach a size that will discourage predation. Headstarted turtles may be kept in captivity from several months to a few years before they are released. There are two purposes: to boost populations, and/or to establish new nesting sites (most often used with sea turtles). Although some have argued that headstarting turtles increases their chances for survival, others believe that headstarting is useless if it does not address other causes of species decline. In some cases, it may actually be harmful to turtles.

Headstarting directly interferes with the early life stage of the turtle, is tremendously complex, and has the potential for harm if done incorrectly. Wildlife rehabilitators should not undertake headstarting projects on their own. Headstarting, if used at all, should only be attempted as part of a controlled research study conducted within scientific parameters. Without careful study, research, controls and knowledge, headstarting can physiologically and psychologically harm hatchlings, and potentially endanger wild populations.

\section{EMERGENCY OVERWINTERING IS NOT THE SAME AS HEADSTARTING}

On occasion, situations arise whereby a hatchling or group of hatchlings must be overwintered. These are emergency situations that are usually encountered when a hatchling is ill or injured and requires extended care, is found in the wild at a time when weather conditions prevent an immediate return (i.e., an abnormally warm November day that brings the turtle out of hibernation), hatching too late in the year for a safe release, or a nest containing hibernating hatchlings is disturbed or destroyed. Overwintering does deprive the hatchling of a normal start in life.

Harriet Forrester is a New Jersey state licensed wildlife rehabilitator and the founder of Turtle Rescue of New Jersey.
However, in these emergency situations, the turtle would not survive at all without assistance. This is not the same as deliberately keeping healthy turtles in captivity for the purpose of headstarting.

\section{Causes of TuRTLe Decline}

The reason most often stated for headstarting turtles is protection from predators. However, turtles and their natural predators have been around for 200 million years. Natural predation is not causing turtle numbers to decline. Human-related activity is the number one cause of turtle population decline.

Pollution, habitat loss from over-development, being hit by cars and lawn mowers, drowning in nets from shrimp, fishing, and crab operations, and collection for pets and food are the foremost problems faced by turtle populations today. These human-related threats affect all turtle and tortoise species in every part of the world (Moll and Moll 2000; Gibbons et al 2000; Gibbons et al 2001; McDougal 2000; Settle 1995; Garber and Burger 1995).

A major concern regarding headstarting is that it does not address these root causes of population decline (Pritchard 1980; Hewavisenthi and Kotagama 1990; Frazer 1992; Heppell et al 1996; National Research Council 1990). "Headstarting is useful only when used in tandem with a strategy that will reduce the loss of adults" (Klemens 1993).

\section{LESSONS FROM SEA TURTLE HEADSTARTING}

The most completely documented headstarting programs have been done with sea turtles. After more than 30 years, the results are inconclusive at best. The serious problems encountered and lack of proven successes have led to most of these programs being discouraged or discontinued (Sea Turtle Restoration Project 1995; Seigel and Dodd 2000; Huff 1989; Great Barrier Reef Marine Park Authority 2005; Bryant 2002). 


\section{DETRIMENTAL EFFECTS OF HEADSTARTING TURTLES}

Wildlife rehabilitators care for sick, injured and orphaned wildlife in order to return a fully functioning animal to the wild. With this goal in mind, and based on the concerns raised by the sea turtle projects, many issues must be addressed regarding wildlife rehabilitators headstarting turtles.

Natural Life Cycle. Headstarting interferes with the natural life cycle of normal healthy hatchlings. In the wild, turtles have no maternal care and are capable of finding food, water, hiding places, and hibernation spots the moment they emerge from the nest. Healthy hatchlings are, by definition, neither sick, injured, nor orphaned. There is no justification to disrupt this critical early life stage by keeping them in captivity under completely artificial circumstances. "Disrupting an animal's natural behavior and subjecting them to experiments without required controls or measurability is not scientifically legitimate management" (Woody 2001).

\section{Incubation Conditions.}

Incorrect artificial incubation can impact hatchlings and their survival ability. In many turtle species, the temperature at which the eggs are incubated determines the sex of the developing embryo. Temperatures off by only two or three degrees can skew sex ratios. Improper incubation conditions, including temperature, air flow, substrate material, and humidity, can produce weak or deformed hatchlings, and even cause an entire clutch to fail to develop. Correct incubation temperatures, humidity, and substrate information can be found in the references listed under Recommended Reading, as well a number of other sources, and wildlife rehabilitators should consult these before attempting to artificially incubate turtle eggs.

Human Exposure. Human interference and headstarting can have behavioral impact on hatchling turtles. Turtles that are consistently exposed to humans and human activity may become habituated and can lose their natural fear. Since humans are the number one predator of turtles, a fearless, habituated turtle will probably not survive long in the wild. For example, turtles in captivity rapidly learn that humans are the food source, and headstarted turtles may continue to associate the presence of humans with food (Pritchard 1980).

Development. A hatchling's development, both physiologically and psychologically, can be negatively impacted by captivity. According to Woody (1990) “...it doesn't take a genius to figure out that life in a bucket or raceway with a kind person dumping in prepared food pellets once a day is not what the real world is all about." The following husbandry condi-

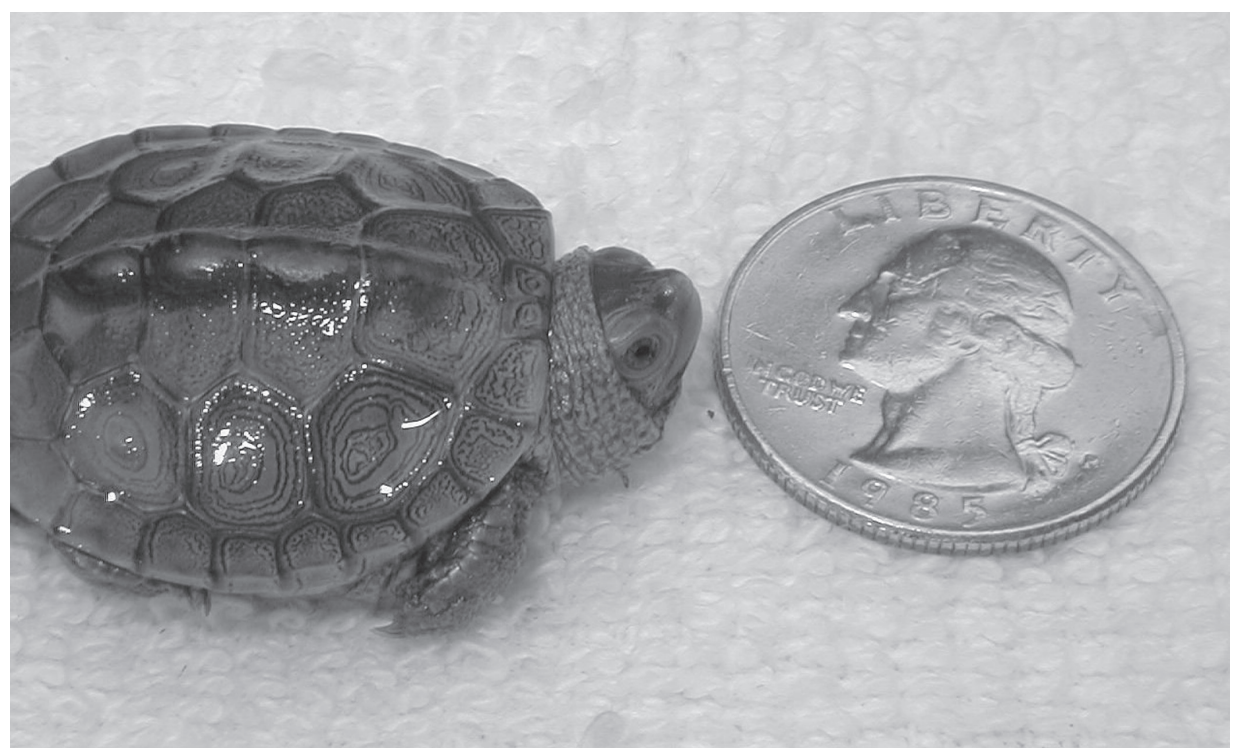

Hatchling diamondback terrapin (malaclemys terrapin).

tions have great influence on the proper physiological and psychological development of hatchlings:

Space-Headstarting is often done by rehabilitators using small containers, typically $2 \mathrm{ft} \times 1 \mathrm{ft} \times 1 \mathrm{ft}$ $(61 \mathrm{~cm} \times 30.5 \mathrm{~cm} \times 30.5 \mathrm{~cm})$, to raise hatchlings. Due to the limited space available for exercise, hatchlings will be lagging behind their wild counterparts in the muscle tone and stamina necessary to thrive in their natural environment. Tupperware ${ }^{\mathrm{TM}}$ (Tupperware Corporation, Orlando, FL) or Rubbermaid ${ }^{\mathrm{TM}}$ (Rubbermaid, Inc., Wooster, $\mathrm{OH}$ ) containers with minimal or no furnishings are not suitable habitats. Captive environments must be enriched, which increases the well being of the turtles by reducing stress, inducing exercise, and providing stimulation.

Crowding-Often, hatchlings are kept together in these small containers. In the wild, turtles do not congregate for any activity other than basking. Keeping a number of hatchlings together at all times in small spaces is abnormal and will increase stress, aggression, and food competition.

Water quality and levels-Even if water is filtered, 
it must still be changed frequently. This usually entails handling the hatchlings which gives rise to habituation concerns. The practice of keeping aquatic hatchlings in shallow water is an unnatural situation for them and limits the development of muscle tone and stamina.

Lighting-Incorrect levels of UV (ultraviolet) light can cause harm and behavioral disruption. UVB is needed to produce Vitamin $\mathrm{D}_{3}$, which is necessary to metabolize calcium. UVA stimulates normal behaviors such as basking and eating. Turtles can see into the ultraviolet range of light (Ammermuller et al 1998; Arnold and Neumeyer 1987; Ventura et al 2001) and using the wrong lights can actually affect the way turtles visualize food items.

Photoperiod-Many reptiles obtain physiological cues from light/dark cycles. Inconsistent photoperiods or constant light or dark environments induce stress. Light intensity and photoperiod can also affect hormone and neurotransmitter activity in chelonians, which in turn can impact food intake, stress levels, wound healing, and normal behavior (Vivien-Roels et al 1988; Kinsey et al 2003; Mahapatra et al 1988).

Temperature-As ectotherms, turtles depend on external sources to regulate their body temperature. The proper temperatures and temperature gradients are required for their metabolic processes to function. Temperature gradients are nearly impossible to achieve in the small containers typically used by rehabilitators.

Substrate-Natural substrates such as sand, gravel, or soil, are usually eliminated from headstarting habitats for ease of cleaning. However, bare tanks, or containers with newspaper on the bottom, prevent hatchlings from engaging in many normal behaviors. For example, aquatic turtles naturally forage for food in the soil and stones at the bottom of ponds, while snapping turtles spend much of their time buried in the mud at the water's edge. For box turtle hatchlings, a deep moist substrate is necessary to prevent chronic dehydration; a water bowl alone is not enough to maintain correct hydration.

\footnotetext{
Altered Feeding Behavior. Feeding behaviors and preferences are altered by captivity. Studies with turtles have shown that foods experienced early in life are preferred over those experienced later, and this can affect feeding choices throughout life. It has also been suggested that there is a food/olfactory 'imprinting' in turtles (Burghardt 1977; Burghardt and Hess 1966). Unfortunately, it is difficult to duplicate a complex natural wild diet in captivity. Store-bought plants
}

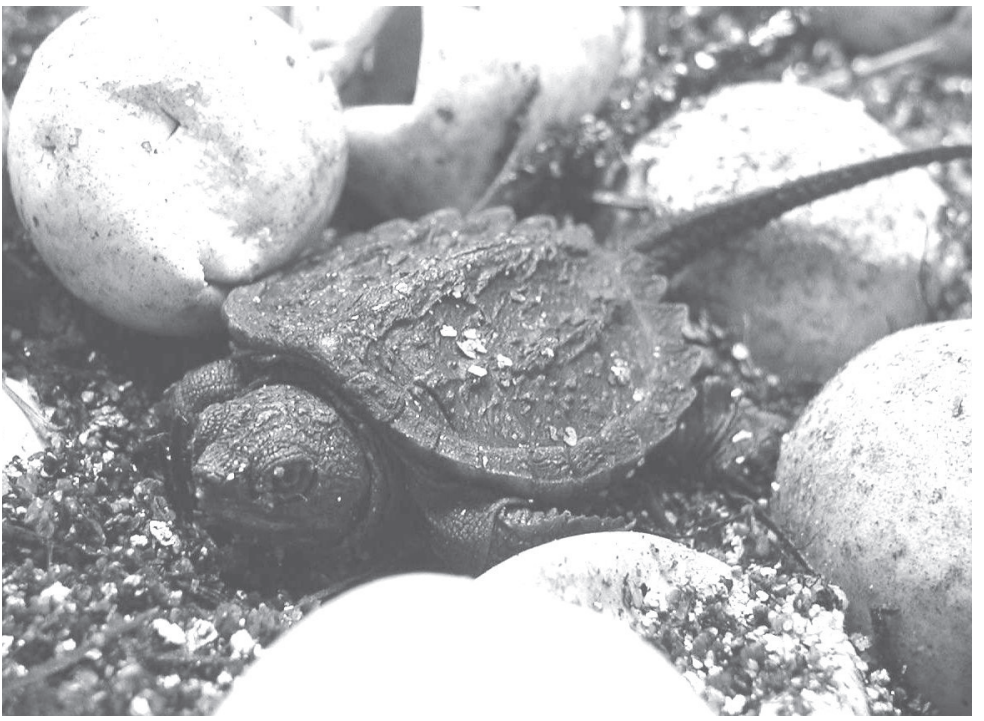

Newly-hatched snapping turtle (chelyora serpentina).

and domestic prey (such as mice) may differ from wild varieties in nutrient content, appearance, and taste (Donoghue 1996). If hatchling turtles are fed diets that look, smell, and taste different from wild foods, they may become dependent on food that is not available to them after release.

Nutritional deficiencies. Nutritional problems can be encountered in headstarting, including vitamin, mineral, and protein deficiencies, overfeeding and obesity, and general malnutrition. There is no room for error in the diet of hatchlings. Most commercial diets are made from fish and crustacean meals. Mineral and vitamin contents of fish meals vary with species used, season of harvest, and processing techniques. Some processing techniques used in extrusion and pelleting commercial products involve high temperatures that partially destroy vitamins (Donoghue 1996).

Calcium deficiency, one of the most frequent and serious nutritional problems encountered in raising captive turtles, can result in metabolic bone disease. Both lack of calcium and excessive phosphorus are implicated in this problem. A good diet will have calcium/phosphorus $(\mathrm{Ca} / \mathrm{P})$ ratios of at least 2:1. Mealworms and crickets, which are items frequently used to feed hatchling turtles, have extremely poor $\mathrm{Ca} / \mathrm{P}$ ratios of 1:10 or worse (Barker et al 1998; Finke 2002). High phosphorus levels may cause secondary hyperparathyroidism, bone resorption, and calcification of the kidneys and heart (Donoghue 1996).

Abnormal growth. Accelerated growth can harm hatchlings. Some headstart programs deliberately accelerate the growth of hatchlings to ensure that they 
are large upon release. Excessive growth rates in hatchlings have been associated with high mortality, renal disease, and irreversible deformities of the skeletal system (McArthur et al 2004).

Disease Risks. Captive reared turtles can introduce disease to wild populations. A turtle can be a carrier of a pathogen (bacterial or viral infections, or parasite loads), and still look and act perfectly healthy. According to Jacobson (1996), "Certain pathogens, and the diseases they produce, are amplified in captivity, particularly in aquatic systems. Releasing infected, asymptomatic turtles into unexposed wild populations can result in disasters; that is, can result in major episodes of mortality." Releasing captive reared animals into the wild will always carry the risk of inadvertent introduction of disease and parasites (Bell et al 2005).

\section{HATCH AND RELEASE-THE Alternative to HeAdstarting}

There are times when rehabilitators have to hatch turtle eggs. Gravid females may lay their eggs during rehabilitation, or eggs may be removed from a female that died. To ensure the best start in life for the resulting hatchlings, they should be released as soon after hatching as possible. If necessary, hatchling turtles can be kept for a few days to ensure absorption of the yolk sac. During that time, they live off the nutrients in the sacs, so there is no need to feed them. Immediate release introduces the hatchling turtle to its natural, wild habitat without any disruption from its natural life cycle. Turtles will not get habituated during this short time, and normal physical and behavioral development will take place in the wild.

\section{CONCLUSION}

Headstarting is not a proven technique. Short-term survival during the headstarting period and the appearance of health are not indicators that a truly healthy fully-functioning turtle has been released to the wild. Turtles have been known to survive abysmal husbandry, horrific diets, injuries that would have killed another species, freezing, and even euthanasia attempts.

Research has shown that headstarting is not a valid recovery strategy; furthermore, it does not deal with the major causes of turtle decline-humans and their related activities. Comprehensive turtle recovery projects must simultaneously address all aspects of the problem: captive breeding, headstarting in some circumstances, predator control, habitat protection, public education, and long-term longitudinal studies. The research, planning, and expense required for such a project is beyond the resources of most rehabilitators. However, without that research, planning, and follow-up, headstarting is just a guessing game. If the guesswork is wrong, the turtles are the ones that pay the price.

\section{LiterATURE CITED}

Ammermuller, J., A. Itzhaki, R. Weiler, and I.

Perlman. 1998. UV sensitive input to horizontal cells in the turtle retina. European Journal of Neuroscience. 10(4): 1544.

Arnold, K., and C. Neumeyer. 1987. Wavelength discrimination in the turtle Pseudemys scripta elegans. Vision Research. 27(9):1501-11.

Barker, D., M. Fitzpatrick, and E. Dierenfeld. 1998. Nutrient composition of selected whole invertebrates. Zoo Biology. 17(2):123-34.

Bell, C. D. L., J. Parsons, T. J. Austin, A. C. Broderick, B. Ebanks-Petrie, and B. J. Godleyy. 2005. Some of them came home: the Cayman Turtle Farm headstarting project for the green turtle Chelonia mydas. Oryx. 39(2):137-148.

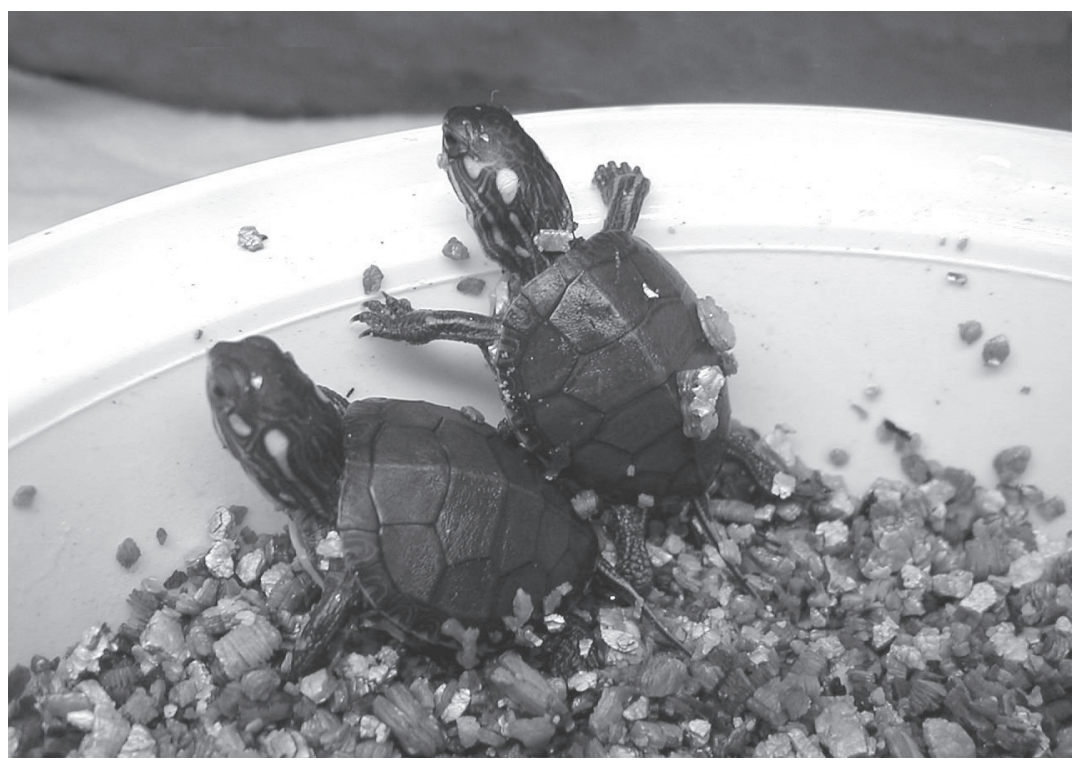

24-hour-old painted turtles (chrysemys picta) ready to go.

Bryant, P. J. 2002. Chapter 23: Captive Breeding and Reintroduction in Biodiversity and Conservation: A Hypertext Book, School of Biological Sciences, University of California: Irvine, CA. < http://darwin.bio.uci.edu/ sustain/bio65/ Titlpage.htm >.

Burghardt, G. M. 1977. Learning processes in reptiles. Pp. 555-707 in Biology of the Reptilia, vol. 7 
(C. Gans, and T. S. Parsons, eds.). Academic Press: New York, NY.

Burghardt, G. M., and E. H. Hess. 1966. Food imprinting in the snapping turtle, Chelydra serpentina. Science. 151:108-109.

Donoghue, S. 1996. Nutrition. Pp. 148-174 in Reptile Medicine and Surgery (D. Mader, ed.). W. B. Saunders Company: Philadelphia, PA.

Finke, M. 2002. Complete nutrient composition of commercially raised invertebrates used as food for insectivores. Zoo Biology. 21(3):147-62.

Frazer, N. B. 1992. Sea turtle conservation and halfway technology. Conservation Biology. 6(2):179-184.

Garber, S. D., and J. Burger. 1995. A 20-Year Study Documenting the Relationship Between Turtle Decline and Human Recreation. Ecological Applications. 5(4):1151-1162.

Gibbons, J. W., D. E. Scott, T. J. Ryan, K. A. Buhlmann, T. D. Tuberville, B. S. Metts, J. L. Greene, T. Mills, Y. Leiden, S. Poppy, and C. T. Winne. 2000. The Global Decline of Reptiles, Déjà vu Amphibians. Bio Science. 50(8):653-666.

Gibbons, J. W., J. E. Lovich, A. D. Tucker, N. N. Fitzsimmons, and J. L. Greene. 2001. Demographic and Ecological Factors Affecting Conservation and Management of the Diamondback Terrapin (Malaclemys terrapin) in South Carolina. Chelonian Conservation Biolology. 4(1):66-74.

Great Barrier Reef Marine Park Authority. 2005. Policy on Managing Activities that include the Direct Take of a Protected Species from the Great Barrier Reef Marine Park, Australia.

Heppell, S. S., L. B. Crowder, and D. T. Crouse. 1996. Models to Evaluate Headstarting as a Management Tool for Long-Lived Turtles. Ecological Applications. 6(2):556-565.

Hewavisenthi, S., and S. W. Kotagama. 1990. The effect of retaining turtle hatchlings in tanks before their release. Proceedings Sri Lanka Assoc. Science. 56(1):92.

Huff, J. A. 1989. Florida (USA) terminates "headstart" program. Marine Turtle Newsletter. 46:1-2.

Jacobson, E. R. 1996. Marine Turtle Farming And Health Issues. Marine Turtle Newsletter. 72:13.

Kinsey, S. G., B. J. Prendergast, and R. J. Nelson. 2003. Photoperiod and stress affect wound healing in Siberian hamsters. Physiology $\mathcal{E}$ Behavior. 78(2003):205-211.

Klemens, M. W. 1993. A New Paradigm for Conservation. Pp. xv-xvii in Conservation, Restoration, and Management of Tortoises and TurtlesAn International Conference, Proceedings
(J. Van Abbema, ed.). New York Turtle and Tortoise Society: New York, NY.

Mahapatra, M. S., S. K. Mahata, and B. R. Maiti. 1988. Circadian rhythms and influence of light on serotonin, norepinephrine, and epinephrine contents in the pineal-paraphyseal complex of soft-shelled turtles (Lissemys punctata punctata). General and Comparative Endocrinology. 71(1):183-8.

McArthur, S., R. Wilkinson, and J. Meyer. 2004. Pp. 83 in Medicine and Surgery of Tortoises and Turtles. Blackwell Publishing: Ames, IA.

McDougal, J. 2000. Conservation of Tortoises and Terrestrial Turtles. Pp. 180-206 in Turtle Conservation Biology, (M. Klemens, ed.). Smithsonian Institution Press: Washington, DC.

Moll, E. O. and D. Moll, 2000. Conservation of River Turtles. Pp. 126-155 in Turtle Conservation Biology, (M. Klemens, ed.). Smithsonian Institution Press: Washington, DC.

National Research Council. 1990. Decline of the Sea Turtles: Causes and Prevention. National Academy Press: Washington, DC.

Pritchard, P. C. H. 1980. The conservation of sea turtles: practices and problems. American Zoologist. 20(3):609-617.

Sea Turtle Restoration Project. 1995. Report on Guatemala's Hatchery Programs $<$ http://www.seaturtles.org/progMaterial.cfm?ca mpaignMaterialID $=30>$.

Seigel, R. A., and C. K. Dodd, Jr. 2000. Manipulating Turtle Populations: Half-way Technologies or Viable Options? Pp. 218-238 in Turtle Conservation Biology, (M. Klemens, ed.). Smithsonian Institution Press: Washington, DC.

Settle, S. 1995. Status of Nesting Populations of Sea Turtles in Thailand and Their Conservation. Marine Turtle Newsletter. 68:8-13.

Ventura, D. F., Y. Zana, J. M. deSouza, and R. D. DeVoe. 2001. Ultraviolet colour opponency in the turtle retina. Journal of Experimental Biology. 204:2527-2534.

Vivien-Roels, B., P. Pevet, and B. Claustrat. 1988. Pineal and circulating melatonin rhythms in the box turtle, Terrapene carolina triunguis: effect of photoperiod, light pulse, and environmental temperature. General and Comparative Endocrinology. 69(2):163-73.

Woody, J. B. 1990. Is 'Headstarting' a Reasonable Conservation Measure? On the Surface, Yes; in Reality, No. Marine Turtle Newsletter. 50:8-11.

Woody, J. B. 2001. It's Time to Stop Headstarting Kemp's Ridley. Marine Turtle Newsletter. 55:7-8. 
(Forrester, continued.)

\section{RECOMMENDED READING}

Ernst, C. H., J. E. Lovich, and R. W. Barbour.

1994. Turtles of the United States and Canada.

Smithsonian Institution Press: Washington, DC.

Highfield, A. C. 1996. Practical Encyclopedia of Keeping and Breeding Tortoises and Freshwater Turtles.

Carapace Press: London, England.

Dodd, K. C., Jr. 2001. North American Box Turtles: A Natural History. University of Oklahoma Press: Norman, OK. (NRR

(Lord, continued.)

\section{RECOMMENDED READING}

Lord, J., D. Nickerson, and E. Thrune. 2004. Introduction to Wildlife Education Programming: Tips $\mathcal{E}$ Techniques for Better Presentations. National Wildlife Rehabilitators Association: St. Cloud, $\mathrm{MN}$. (N⿴囗十)

(Miller, continued.)

It is hoped that this will encourage wildlife rehabilitators to look for other applications of some of these ideas to provide psychological and environmental enrichment for infant wild creatures, whether in a home based setting or in a rehabilitation center. In particular, the surrogate mother figure was so successful with the beavers that the author would be interested in hearing from others if they successfully make use of the device for other mammal species.

\section{ACKNOWLEDGEMENTS}

The author would like to thank Mammal Intern Catherine Britt for her dedicated assistance in working with the beavers and for her help in sorting through the records for this article. Thanks also to Cynthia Bolding and Kathy Early for their creativity in helping to provide a nurturing environment for the beavers. Special thanks to Carol McWhorter for drawing the diagram of 'Mother Beaver' for this article.

\section{LITERATURE CITED}

Marcum, D. 1997. Rehabilitation of North American Wild Mammals, Feeding and Nutrition. Self-published.

[Editor's Note: Rehabilitators may have difficulty locating a copy of the Marcum publication cited for this article. The NWRA Principles of Wildlife Rehabilitation, The Essential Guide for Novice and Experienced Rehabilitators contains much of Debbie Marcum's information in the Mammal Nutrition chapter.] (N.
(McFarland, continued.)

Purell.com [homepage on the Internet]. Pfizer, Inc:

New York, NY. Available from:

$<$ http://www.purell.com/index.aspx >.

Schloss, P. D., and J. Handelsman. 2004. Status of the microbial census. Microbiology and Molecular Biology Reviews. 68(4):686-91.

Smith, H. 1972. Mechanisms of virus pathogenicity. Bacteriology Reviews. 36(3):291-310.

Taubenberger, J. K. and D. M. Morens. 2006. Influenza revisited. Emerging Infectious Diseases. 12(1):2.

usyd.edu.au [homepage on the Internet]. School of Biological Sciences, University of Sydney: Sydney, NSW. [updated 2004 June]. Available from: <http://bugs.bio.usyd.edu.au/Mycology/Animal_ Interactions/Disease/humanDisease.html>.

Whitman, W. B., D. C. Coleman, and W. J.

Wiebe. 1998. Prokaryotes: the unseen majority. Proceedings of the National Academy of Sciences USA. 95(12):6578-83.

\section{RECOMMENDED READING}

Balows, A., W. Hausler, Jr., K. L. Herrmann, H. D. Isenberg, and H. J. Shadomy. 1991. Clinical Manual of Microbiology. 5th edition. American Society for Microbiology: Washington, DC.

CDC.gov [homepage on the Internet]. Centers for Disease Control and Prevention: Atlanta, GA. Available from: <http://www.cdc.gov/ncidod/ EID/vol8no4/01-0273.htm>.

Discover.com [homepage on the Internet]. Discover: New York, NY. [updated 2004 January]. Available from: < http://www.discover.com/issues/jan-04/ features/botany/ $>$. (․ㅏㄹ

FROZEN: RATS, MICE \& CHICKS

shipped anywhere in the USA www.frozenrodents.com

PERFECT PETS INC. 23180 SHERWOOD

BELLEVILLE, MI 48111

(800) $366-8794$

FAX (734) 461-2858 